
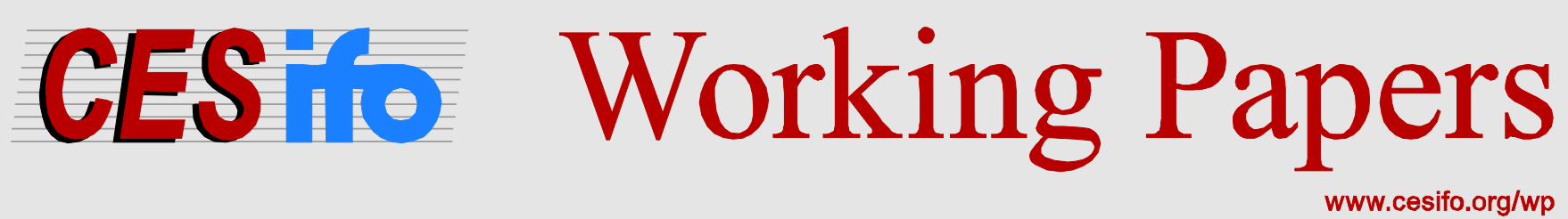

\title{
Migration and Redistribution: Why the Federal Governance Structure of the Economic Union Matters
}

\author{
Assaf Razin \\ Efraim Sadka
}

CESIFO WORKING PAPER NO. 5920

CATEGORY 1: PUBLIC FINANCE

MAY 2016

An electronic version of the paper may be downloaded

- from the SSRN website:

- from the RePEc website:

- from the CESifo website: WWW.SSRN.com

Www.RePEc.org

www.CESifo-group.org/wp

ISSN 2364-1428

\section{CESifo}




\title{
Migration and Redistribution: Why the Federal Governance Structure of the Economic Union Matters
}

\begin{abstract}
We argue that the degree of coordination among the member states potentially contribute a great deal to our understanding of observed policy differences between the EU and the US as economic unions: the generosity of the welfare state and the skill composition of migration.
\end{abstract}

Assaf Razin Department of Economics

Tel-Aviv University Israel - Tel Aviv 69978

razin@post.tau.ac.il
Efraim Sadka

The Eitan Berglas School of Economics

Tel-Aviv University

Israel - Tel Aviv 69978

sadka@post.tau.ac.il

May 2016 


\section{1: $\underline{\text { Introduction }}$}

In this paper we analyze the role the federal governance structure plays in the income redistribution and migration policies.

A central tension faced by policy makers in countries that receive migrants from lower wage countries. The former countries are typically highly productive and capital rich. The resulting high wages attract both high-skill and low-skill migrants. Reinforcing this migration is the nature of the host country's welfare state: low-skill migrants find a generous welfare state particularly attractive. Such a welfare state may turn also to be a migration state. Low-skill migration imposes a fiscal burden on the native-born. In addition, a generous welfare state may deter high-skill migration because heavy redistributive taxes must accompany them. Indeed, over the last half-century, Europe's generous social benefits have encouraged a massive surge of "welfare migration”, that is, of low-skill migrants. In contrast, at the same period, the U.S. has attracted a major world portion of high-skill migrants, boosting its innovative edge. While Europe ended up in the last two decades with 85 percent of all lowskill migrants to developed countries, the US retains its innovative edge by attracting 55 percent of the world-educated migrants. In other words, European migration exhibits a bias towards low-skilled workers, whereas the US attracts the majority of the world's skilled migrants. At the same time, the welfare system in Europe is more generous than the one in the US.

\section{1,1 Differences in the Federal Systems}

Both the EU member states and US states are organized as economic unions.

An economic union is a single market for goods, capital, finance, and labor. That is, there is free mobility of goods, physical and financial capital, and labor among the member countries of the union. Both the EU and the US are also of a similar economic size, income per capita, culture, technology, etc. 
However, they differ fundamentally in their federal systems. The federal system in the EU is loose, with predominant sovereignty residing in the member states, whereas the federal system in the US is robust, with fiscal and migration policies reside at the federal level.

At the time the European Union is born, all the major individual countries have already well-established solid fiscal systems and none was at a risk of default. As a result, the individual countries preserved their fiscal independence from the outset There is no EU-wide income tax, no health care programs (such as, for instance, Medicare, and Affordable Care), and no social security payroll taxes in the EU. The EU budget amounts to no more than one percent of the GDP in the EU.

Fiscal union in the US starts with Alexander Hamilton after the revolutionary war, when state governments were insolvent. For the US treasury to be credit worthy in the global market the nascent federal government (with its taxing power), assumed state debts.

A later wave of state fiscal crises in the mid of the nineteenth century enhanced the federal government to take a leading role in financing infrastructure projects, allowing state governments to reduce their role. Following the debt crises, many states introduced some forms of balanced budget rules into their constitutions; see Sargent (2012).

This enhanced the role of the federal government in the fiscal system. Nowadays, federal tax revenues constitute well over one-half of all the tax revenues (federal, state and local) in the U.S. 


\section{1,2 Differences in the Income - Redistribution policies}

The figure below illustrates the US-EU differences in income redistribution.

The income inequality metric at play is a number between 0 and 1 known as the Gini coefficient. In a hypothetical country with a coefficient of 0 , everyone has exactly the same income, while a nation with a coefficient of 1.0 is home to one fat cat who takes everything while everyone else earns nil. At 0.0.57, before taxes and transfers, and 0.42, after taxes and transfers, America's redistribution reduces GINI by 0.15 ; whereas the corresponding effects of redistribution on the GINI are : Germany $-0.60-0.36=0.24$, and Denmark - 0.56-0.33=0.24.

\section{Income Inequality and Redistribution}

The U.S. government does less than many other rich countries to reduce marketgenerated income inequality.

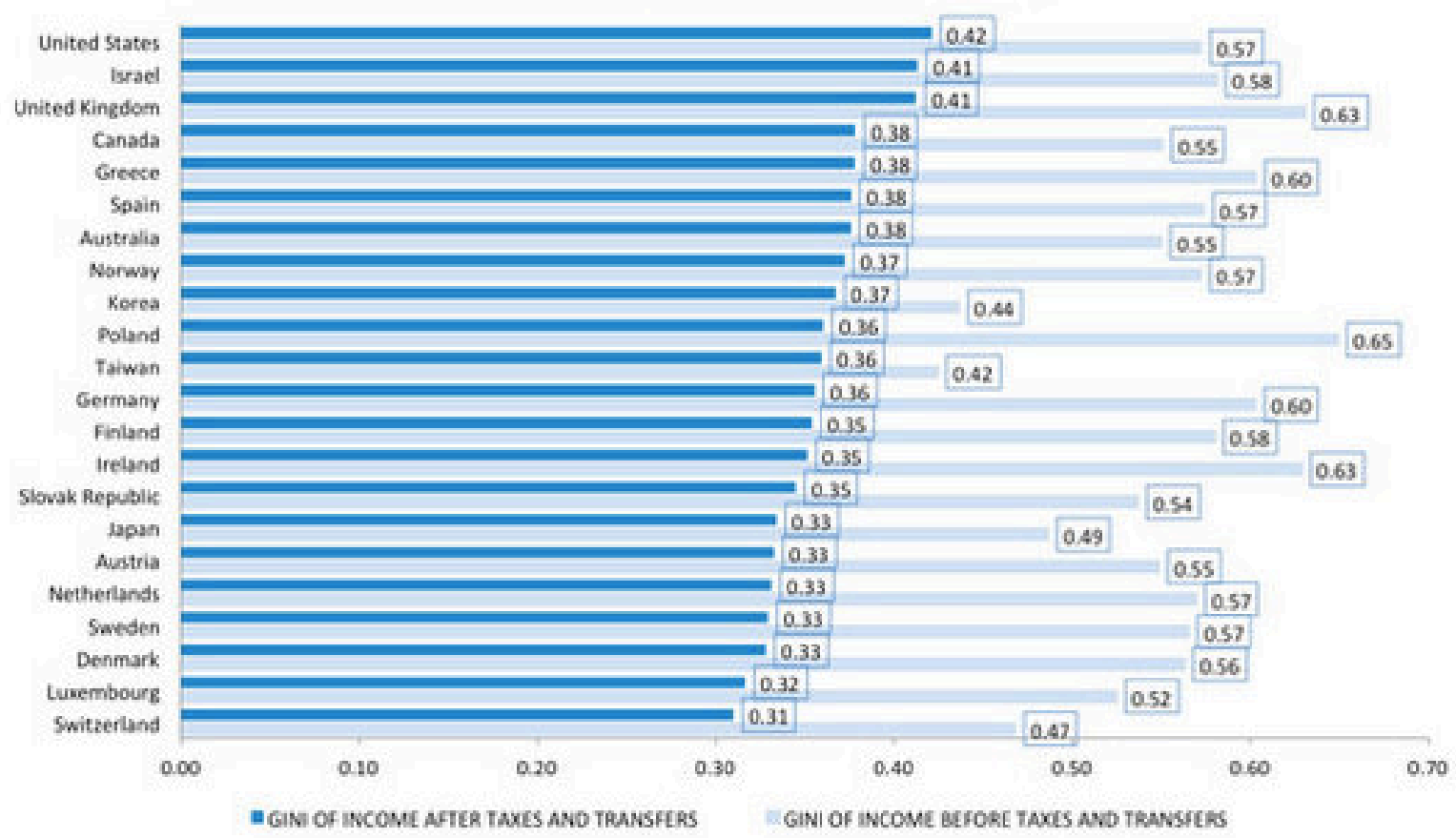

Source: Author's calculations, 2013, based on LIS microdata, most recent datasets avallable (early to mid-2000s)

Source: Janet Gornick (2013) 
An alternative measure of the effects of income redistribution is to consider the magnitude of social expenditures. The figure below describes the trends of the social expenditures per capita in the US and countries in the core EU. For example, total social expenditures in 2000 amounted to 8,618 USD in Denmark, 7,583 USD in Germany, 8,040 USD in France, 8,668 USD in Sweden, but only 5,838 USD in the U.S. (Data: OECD library).

The time path of the US social expenditures also lies uniformly below the corresponding paths of EU member states.

Social Expenditures per capita: US vs. Core Europe: The Trends

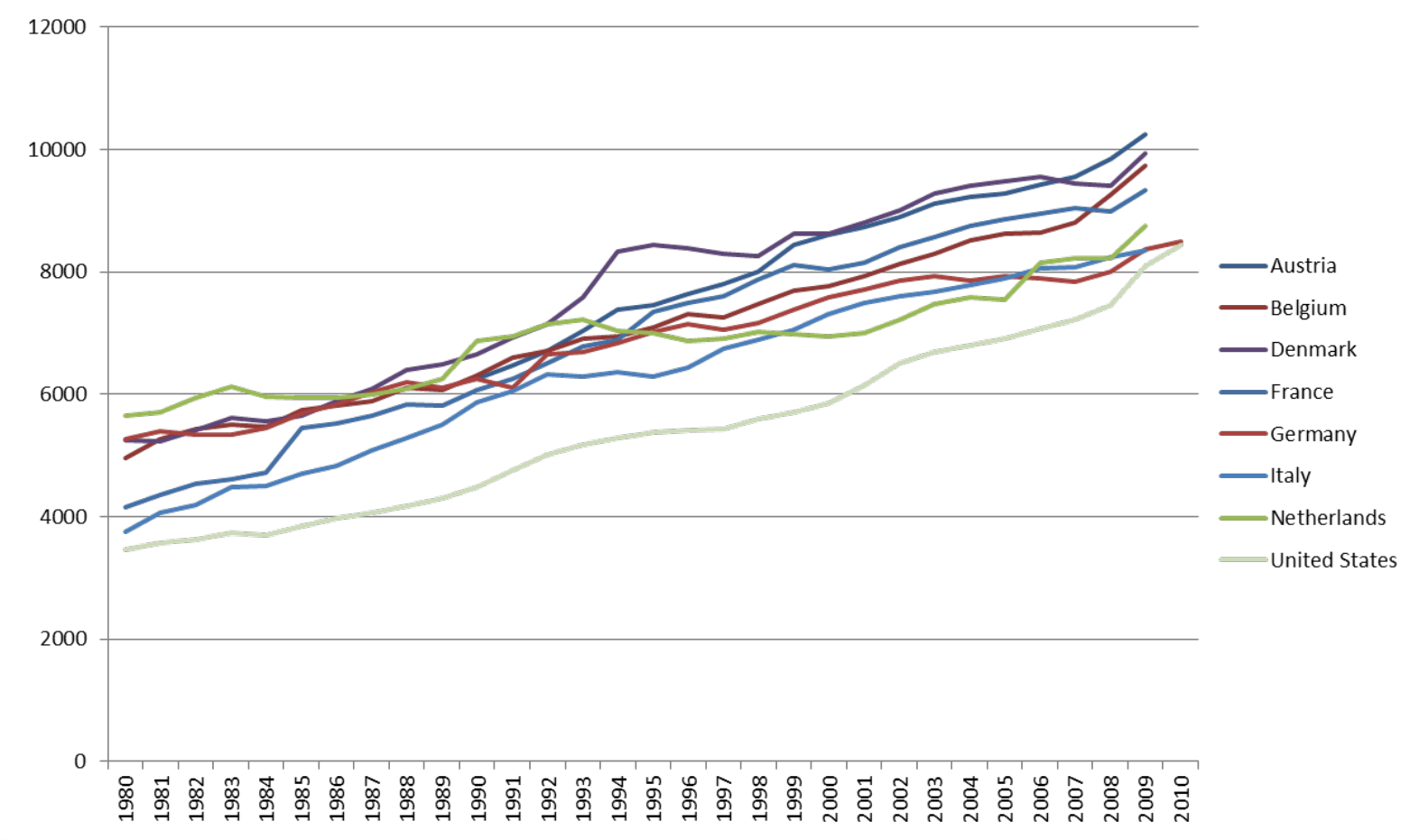

Notes:

Constant PPP 2000 prices

Public and mandatory private social expenditures 


\title{
1.3 Differences in skill composition
}

Overall, and unlike the U.S. migration, the European migration exhibit significant bias toward low-skill migrants; see Boeri, Hanson and McCormick (2002) and Boeri (2008).Table 1 compares the stocks of migrants, by educational attendance, between the EU-15 and the U.S. Indeed, we can see that more than $40 \%$ of the stock of migrants in the U.S. is with tertiary education, whereas the corresponding figure for the EU-15 is less than 25\%. Similarly, about $48-59 \%$ of the stock of migrants in the EU-15 has only primary education, whereas the corresponding figures for the U.S. are only 22-26\%.

Table 1: The Stocks of Migrants, by Education-Level, the U.S. and the EU-15, 1990 and 2000.

Education-Level

(By Percentage of Total)

$\underline{2000}$

Primary

$59 \quad 48$

26

22

Secondary

$24 \quad 28$

31

36

Tertiary

$\underline{18 \quad 24}$

$\underline{43}$

$\underline{24}$

$100 \quad 100$

$\underline{1990}$

$\underline{1990 \quad 2000}$

U.S.

\author{
(1)
}




\subsection{What's the Paper about}

This paper develops an analytical model to explain how the difference between the EU and the US in the way member states are organized in a supranational system lead to key policy differences between the two otherwise similar economic unions: (i) The higher generosity of the welfare-migration system in the EU, relative to the U.S., (ii) The skill and the wealth bias of the migration to the U.S. relative to the migration to EU, with the former receiving a higher portion of the high-skill and rich migrants.

The organization of the paper is as follows. Section 2 discusses policy competition. Section 3 illustrates the effect of migration on the various income groups. Section 4 presents the model. Section 5 compares the policy competition regime and the policy coordination regime. Section 6 concludes.

\section{Policy Competition}

The pioneering framework for competition among jurisdictions is due to Tiebout (1956), who dealt with localities. Tiebout's model features many "utility-taking” localities, analogous to the perfect competition setup of many "price-taking" agents. His focus was on the allocation of a given population among competing localities. ${ }^{1}$ Adopting a similar approach, we model a stylized economy with a group (union) of $\mathrm{n}$ small countries. There is free mobility of goods and capital among them. They are also destination countries for migrants from the rest of the world. These migrants are generally poorer than the native-born residents of these countries. In this chapter we consider a competitive regime in which each country in the union determines its own tax/ benefit and migration policies, in competition with the other countries. The alternative of coordination among the

\footnotetext{
${ }^{1}$ A related issue, fiscal federalism, was first analyzed by Oates (1972).
} 
union's members with respect to the fiscal and migration policies (the coordination regime) is dealt with in the next chapter.

We turn now to a description of the union countries. For the sake of simplicity, we assume that all these countries are identical and we specify the characteristics of a representative country.

\section{Winners and losers from migration}

Like trade in goods, migration also leads to winners, losers but an overall efficiency gains. The figure below illustrates the effect of low-skill migrants on the various income groups, in the absence of government redistribution policies. Migration raises the supply of labor from OC to OF, and lowers the low- skill native- born wage from $\mathrm{OH}$ to $\mathrm{OR}$. The low-skill, native- born loss is equal to HARK ;

the high-skill Labor and capital owner gain is equal to HARK+AKC; and The efficiency Gain is equal to AKC. The efficiency gains typically can not be exploited so as to compensate the losers ( without harming the winners ) because of political-economy constraints. 


\section{Redistribution of Gains and Losses}

from low-skill Migration

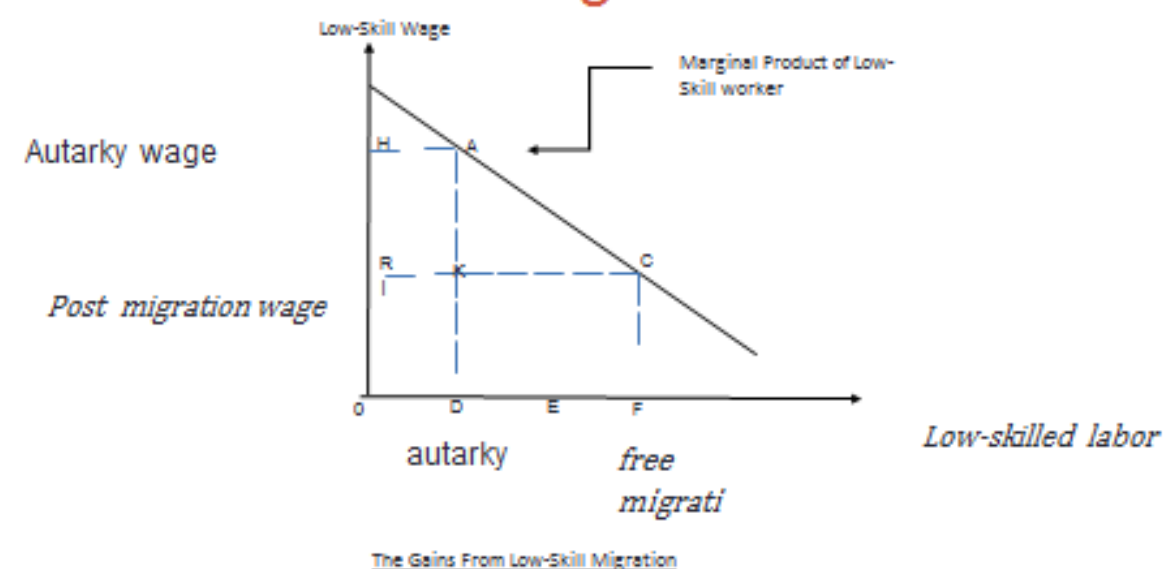

4, The Model

The model assumes free mobility of goods, people, and capital within an economic union. There exists a continuum of states within an economic union competing on people, capital, taxes and social benefits. The supply of migrants from the rest of the world is upward slopping.

\subsection{Representative Country}

With a capital input, the constant-returns-to-scale, Cobb-Douglas production function becomes now

$Y=A K^{\beta} L_{s}^{(1-\beta) \alpha} L_{u}^{(1-\beta)(1-\alpha)}, \quad 0<\alpha<1,0<\beta<1$.

The income shares of the high-skill and low-skill, respectively, are now given by $(1-\beta) \alpha$

and $(1-\beta)(1-\alpha)$, as can be seen from equations (4.2) below. 
The competitive wages of high-skill and low-skill labor are equal to their marginal productivities:

$$
\begin{gathered}
w_{s}=\frac{(1-\beta) \alpha Y}{L_{s}} \\
w_{u}=(1-\beta)(1-\alpha) Y / L_{u}
\end{gathered}
$$

Note that the abundance of high-skill labor raises the wage of the low-skill whereas the abundance of low-skill labor raises the wage of the high-skill.

As before, aggregate labor supply, for high-skill and low-skill workers, respectively, is given $\mathrm{by}^{2}$ :

$$
L_{s}=(S+\sigma \mu) l_{s}
$$

$$
L_{u}=(1-S+(1-\sigma) \mu) l_{u}
$$

As before, the size of the native-born population is normalized to one. Also, the total number of workers, native-born and migrants is given by:

$$
N=1+\mu
$$

For the sake of simplicity, we assume that physical capital does not depreciate. Firms rent capital from individuals. In a competitive equilibrium the pre-tax

\footnotetext{
${ }^{2}$ We also assume that $\frac{\alpha(1-S+(1-\sigma) \mu)}{(1-\alpha)(S+\sigma \mu)}>1$, which ensures that the wage of the high-skill always exceeds the wage of the low-skill $\left(w_{s}>w_{u}\right)$.
} 
rental price of capital (r) will be equal to the marginal productivity of capital, that is

$$
r=\frac{\beta Y}{K}
$$

Native-born high-skill individuals, and low-skill individuals, and migrants differ from one another in their ownership of capital (wealth). Migrants of both types (high-skill and low-skill) own no capital. The native-born high-skill is endowed with more capital than the native-born low-skill. Denote by $\bar{K}_{i}$ the stock of capital owned by a native-born individual with skill level I = s,u , where $\bar{K}_{s}>\bar{K}_{u}$. Given that the high-skill earn a higher wage rate than the low-skill (that is, $w_{s}>w_{u}$ ), it follows that the native-born high-skill are unambiguously richer than the native-born low-skill and all the migrants. Also, the native-born lowskill is richer than the low-skill migrant. Such heterogeneity in income and wealth is crucial for the analysis below.

An individual can rent her capital either at home or at the other union countries. Thus, the total stock of capital, owned by residents, $\mathrm{S} \bar{K}_{s}+(1-\mathrm{S}) \bar{K}_{u}$ does not have to equal $\mathrm{K}$, the total input of capital as would be the case in a closed economy. As explained in the preceding chapter, capital taxation is levied according to the source principle, according to which each country taxes only the capital employed in that country. Denoting the tax rate on capital income by $\tau_{K}$, the netof-tax rental price of capital is $\left(1-\tau_{K}\right) \mathrm{r}^{3}$.

We specify a simple welfare-state system in which there is a dual tax system: a tax at the rate $\tau_{L}$ on labor income and a tax at the rate $\tau_{K}$ on capital income. We allow for different rates of taxation of labor and capital in order to examine the

\footnotetext{
${ }^{3}$ Note that due to our constant-returns-to scale assumption, there are no pure profits at the firm's level that can be taxed (as, for example, by a corporate tax).
} 
effects of migration and capital mobility separately on capital and labor taxation. The welfare state provides also a uniform social benefit (b). The latter may capture not only a cash transfer, but also outlays on public services such as education, health, and other provisions. Thus, $\mathrm{b}$ is not necessarily a perfect substitute to private consumption.

All individuals (irrespective of skill or national origin) have identical preferences over private consumption (c), work efforts (l), and the social benefit (b), given by the following utility function:

$$
u_{i}=c_{i}-\frac{\varepsilon}{1+\varepsilon} l_{i}^{\frac{1+\varepsilon}{\varepsilon}}+\ln (b)
$$

where $\epsilon>0$ is a preference coefficient that will turn out to be the individual labor supply elasticity (see equation (4.8)). Recall that we interpret b not just as a pure cash transfer, but rather as some social benefit that creates a utility of $\ln (\mathrm{b}){ }^{4}$

The budget constraint of a native-born individual with skill level $\mathrm{I}=\mathrm{s}, \mathrm{u}$ is given by:

$c_{i}=(1-\tau) l_{i} w_{i}+\left[1+\left(1-\tau_{K}\right) r\right] \bar{K}_{i} \quad, i=s, u$

We assume that migrants are fully entitled to the welfare system. That is, they pay the tax rate $\tau_{L}$ on their labor income (they own no capital) and receive the social benefit $b$. Thus, the budget constraint of a migrant of a skill levels $i=s, u$ is given by:

\footnotetext{
${ }^{4}$ This quasi-linear utility function is quite common in the tax literature (e.g. Diamond (1998)). It implies that there is no income effect on the labor supply; see equation (7.8) below.
} 


$$
c_{i}=(1-\tau) l_{i} w_{i}
$$

In view of our quasi-linear utility function, capital income does not affect labor supplies. Thus, all individuals (irrespective of skill or national origin) have the same labor supply:

$$
l_{i}=\left((1-\tau) w_{i}\right)^{\varepsilon}, \quad i=s, u
$$

Note that the (fixed) coefficient $\varepsilon$ is indeed equal to the labor supply elasticity.

In general, the indirect utility function gives the maximum level of utility that an individual can obtain, given her budget constraint and the social benefit provided by the government. In our case the indirect utility function is obtained by substituting the labor supply equation (7.9) and the budget constraint (4.7) or (4.8) into the utility function (4.6). Thus, for a native-born individual, this indirect utility function $\left(V_{i}\right)$ is given by:

$V_{i}\left(\tau_{L}, \tau_{K}, b\right)=\ln (b)+\frac{\left(\left(1-\tau_{L}\right) w_{i}\right)^{1+\varepsilon}}{1+\varepsilon}+\left(1+\left(1-\tau_{K}\right)\right) \bar{K}_{i} \quad, i=u, s$

The indirect utility of a migrant who owns no capital is given by

$$
V_{i}^{m}\left(\tau_{L}, b\right)=\ln (b)+\frac{\left(\left(1-\tau_{L}\right) w_{i}\right)^{1+\varepsilon}}{1+\varepsilon}, \quad \mathrm{I}=\mathrm{s}, \mathrm{u}
$$


In a static model, like the present one, it is common and natural to employ a balanced-budget rule ${ }^{5}$. That is, the government employs all its revenues, from labor and capital taxation, to finance the uniform social benefit.

The government budget constraint is thus given by:

$$
b N=\tau_{K} r K+\tau_{L}\left(w_{u} l_{u}+w_{s} l_{s}\right) \quad .
$$

Note that source taxation is employed, so that the government obtains capital tax revenues from the entire input of capital employed in domestic production.

As we have already mentioned, migrants to the union member countries pay their dues to the welfare system, but they also qualify for all the social benefits that the system provides. Therefore, they are not merely driven by better wages, but also by the social benefits. Put differently, migration is driven by the utilitygap rather than by merely the wage-gap. Note that as all the countries of the union are assumed identical, there will be no intra-union migration. Therefore we consider only migration from the rest of the world to union member countries ${ }^{6}$.

However, there is, as before, some cost to migration. As we explained in chapter 5 , some cost to migration. As we explained in chapter 5 , this cost may depend on individual characteristics such as age, family size, ethnicity, whether or not and to what extent pension benefits are portable to the new destination, etc. Thus, the migration cost may vary not only for different skill levels, but also within each skill level. Consequently, the reservation utility - the threshold utility level in the destination country for migration to occur - varies accordingly.

\footnotetext{
${ }^{5}$ This is the analogue of an inter-temporal balanced budget rule, in present value terms, in a multi-period model.

${ }^{6}$ For an extension to a union with non-identical countries and, consequently, intra-union migration from poor to rich member countries (in addition to migration from the rest of the world), see Razin and Sadka (2013).
} 
We assume that would-be migrants are indifferent with respect to the identity of the would-be destination country. All they care about is the level of utility they will enjoy. Thus, the number of migrants of each skill level who wish to emigrate to the union (as a whole) rises with the level of utility (well-being) that they will enjoy in the union. (Note that utilities are identical across the union member countries.)

Put differently, the union faces an upward-slopping migrant supply function for each skill level:

$$
\sigma \mu=f_{S}\left(V_{S}^{m}\right)
$$

$$
(1-\sigma) \mu=f_{u}\left(V_{u}^{m}\right)
$$

where $f_{i}$ is the supply function of migrants of skill level $\mathrm{i}$ and $V_{i}^{m}$ denotes the reservation utility for the marginal migrant; that is, the utility level accorded to migrants of skill level $\mathrm{i}$ in the union, $\mathrm{i}=\mathrm{s}, \mathrm{u}$.

A representative union-member country determines its fiscal and migration policy by majority voting among the native-born. For concreteness, we describe in details the case where the native-born, high-skill form the majority, that is $\mathrm{S}>$ 0.5 (the other case is specified similarly).

Being small enough, each union-member country naturally takes union-wide prices as given. In the presence of free capital mobility there will be only one rental price of capital throughout the union. Because source taxation is em- 
ployed, the relevant price is the net-of-tax rental price of capital ${ }^{7}$. Denote this price (market rate of return) by $\bar{r}$. Therefore:

$$
\left(1-\tau_{K}\right) r=\bar{r}
$$

Prices in our case include also the utility levels of migrants and native-born, by skill.

Because of intra-union free migration, there are therefore also equal utilities, by skill and origin, throughout the union. Each union-member country takes unionwide utility levels ad given too; that is, each country is also a "utility-taker" (in analogy to being a "price-taker”). Denote the (assumed given) union-wide utility level of a migrant of skill i by $\bar{V}_{i}^{m}(\mathrm{i}=\mathrm{s}, \mathrm{u})$.

Then:

$$
\begin{aligned}
& V_{S}^{m}\left(\tau_{L}, b\right)=\bar{V}_{S}^{m} \\
& V_{u}^{m}\left(\tau_{L}, b\right)=\bar{V}_{u}^{m}
\end{aligned}
$$

(Note that because $V_{i}$ and $V_{i}^{m}$ differ from one another only by the term $(1+\bar{r}) \bar{K}_{i}(\mathrm{i}=\mathrm{s}, \mathrm{u})$, which is uniform across the union, it follows that the utilities of the native-born, by skill, are also uniform across the union.)

Taking as given $\bar{V}_{s}^{m} \bar{V}_{u}^{m} \bar{r}$, each union-member country chooses its fiscal and migration policy variables $\left(\tau_{L}, \tau_{K}, b, \mu\right.$, and $\left.\sigma\right)$, so as to maximize the utility of the native-born majority, subject to its budget constraint (4.12), the free capital mobility constraint (4.14), and the intra-union free migration constraint (4.15).

\footnotetext{
${ }^{7}$ If instead residence taxation was employed, then the relevant price would be the pre-tax rental price of capital.
} 


\section{Market - Clearing conditions}

Each union-member country seeks to admit $\sigma^{*} \mu^{*}$ high-skill migrants and (1 $\left.\sigma^{*}\right) \mu^{*}$ low-skill migrants from the rest of the world. The union demands for high-skill and low-skill migrants from the rest of the world are thus $\sigma^{*} \mu^{*} n$ and $\left(1-\sigma^{*}\right) \mu^{*} n$, respectively. (We denote by an asterisk $(*)$ the levels of the economic variables that ensue under the fiscal and migration policy chosen by the government.) Therefore, utility levels that clear the market for migrants from the rest of the world are determined in equilibria by

$$
n \sigma^{*} \mu^{*}=f_{S}\left(V_{S}^{m}\right)
$$

$$
n\left(1-\sigma^{*}\right) \mu^{*}=f_{u}\left(\bar{V}_{u}^{m}\right)
$$

These equations determine the utility levels of the migrants that each union member assumed as given. Also, the world wide net-of-tax rental price of capital, $\bar{r}$, is determined so as to equate the union demand for capital, $n K^{*}$, to the union supply, $n\left(S \bar{K}_{S}+(1-S) \bar{K}_{u}\right)$, that is:

$$
n K^{*}=n\left(S \bar{K}_{S}+(1-S) \bar{K}_{u}\right)
$$

Note that because all the countries in the union are identical, then in equilibrium there is no movement of capital from one country to another; each country em- 
ploys the entire capital endowment of its native-born. But, each member country`s policies are made in an intra-union competitive environments for people and capital.

\section{Intra-Union Coordination}

In the previous section we assumed that the union-member countries compete with each other in an attempt to provide as high as possible utility level for the majority. They compete in the sense that each country determines its fiscal and migration policy variables (i.e. $\tau_{L}, \tau_{K}, b, \mu, \sigma$ ) independently of the other unionmember countries, taking their policies as given (a Nash-equilibrium).

Presumably, a low-skill majority voter opts to admit high-skill migrants, for two reasons: first, such migrants are net contributors to the finances of the welfare state; that is, the tax that each one pays (namely, $\tau_{L} w_{S} l_{s}$ ) exceeds the benefit she receives (namely, b). Second, for a given stock of capital (and volume of migration), increasing the share of high-skill migrants raises the wage of the low-skill (native-born and migrants alike), due to the factor-substitution built-in in the Cobb-Douglas production function. Therefore, if the low-skill forms the majority they will admit only high-skill migrants ${ }^{8}$.

On the other hand, the high-skill (who is assumed to form the majority) may opt for both types of migrants. Low-skill migration raises the wage of the high-skill, due to a factor substitution effect, but imposes a fiscal burden on the high-skill, because low-skill migrants are net consumers of the welfare state. High-skill migration lowers the wage of the high-skill, but contributes positively to the finances of the welfare state. All of these reinforcing or conflicting forces are balanced in a competitive equilibrium. The aforementioned setup may capture the

\footnotetext{
${ }^{8}$ This result hinges crucially on the assumption that migrants are not entitled to vote. If they were, then a lowskill majority may opt to limit the number of high-skill migrants in order to preserve its majority. For an analytical treatment of this case, see Razin, Sadka and Suwankiri $(2011,2015)$.
} 
gist of the policy competition that takes place among the members of the EU. An alternative institutional regime is for the union-member states to coordinate their fiscal and migration policies to their mutual benefit.

This institutional regime of coordination among union-member states may capture the gist of the federal system of the United States. In particular, the federal government is the governing body that set migration policy and the bulk of the fiscal policy. Naturally, such coordination can come only at the expense of the migrants from the rest of the world.

The very advantage of coordination over competition is that the former allows the union-member countries (states) to take into account the effect of policy on economic variables (prices) that each individual country takes as exogenous under competition. The union-member countries are no longer price (utility) - takers in the coordination regime, as they were in the competitive regime. In our case, there are three such variables: the utility level of the high-skill $\left(\bar{V}_{s}^{m}\right)$, the utility level of the low-skill $\left(\bar{V}_{u}^{m}\right)$, and the net-of-tax rental price of capital $(\bar{r})$. These variables govern the allocation of high-skill labor, low-skill labor and capital in the union.

The coordinating states now jointly determine their fiscal and migration policy variables $\left(\tau_{L}, \tau_{K}, b, \mu, \sigma\right)$, as opposed to independently choosing them. In addition and simultaneously, the coordinating states choose now also the "reservation utility prices“-- $\bar{V}_{s}^{m}, \bar{V}_{u}^{m}$, and $\bar{r}$--subject to the market-clearing conditions (5.16) and (5.17). As in the competitive regime, they are also bound by the budget constraints (4.12). Note that as all the union-member states are alike, the issue of revenue-sharing among states does not arise. ${ }^{9}$

\footnotetext{
${ }^{9}$ Note that the "central planner" chose optimally to be on the supply of migrants, rather than ration migration flows.
} 
7. Comparing the Competition Equilibrium to the Coordination Equilibrium

The focus of this paper is the coordination among countries (states) in an economic union affects fiscal and migration policies, as compared to a competition among them. This comparison may offer some explanation to the differences between the U.S. (coordination) and the EU (competition) with respect to the size (generosity) of the welfare state and the share of high-skill migration in total migration.

We consider the social benefit variable (b) as a proxy to the size (generosity) of the welfare state ${ }^{10}$. As there are in our model economy only two types of workers (high-skill and low-skill), we are interested only in the share of just one of these two types of migrants in total migration.

Specifically, we look at the high-skill share $\sigma$. We carry out this comparison via numerical simulations ${ }^{11}$. Figure 9.1 depicts the social benefit (b) under the two institutional regimes (competition and coordination) for different levels of total factor productivity (A). Figure 2 depicts the share of high-skill migration in total migration $(\sigma)$ under the two institutional regimes for different levels of total factor productivity (A). As a side result, we note that the social benefit increases under both regimes when total factor productivity rises. This is expected: a richer economy can afford to accord its residents a higher level of social benefits.

\footnotetext{
${ }^{10}$ Recall that with a balanced-budget the social benefit $b$ are equal to (per-capita) tax revenues. Therefore, the social benefit is more appropriate proxy to the size of the welfare state than the two tax parameters $\tau_{L}$ and $\tau_{K}$, which do not always move in the same direction.

${ }^{11}$ Note that if the low-skilled native born are in the majority, they will opt for high skilled migration only; under both the competitive and the coordination regimes. Because, admitting low-skilled migrants, the low-skilled native born is losing both in the labor-market and the welfare-state fronts.

There is no attempt to calibrate the model to the EU and U.S. economies, as they are very stylized, abstracting from many important features that are similar or different between them. Nevertheless, the simulations offer a useful insight into the quantitative differences between the two unions with respect to fiscal and migration policies.
} 


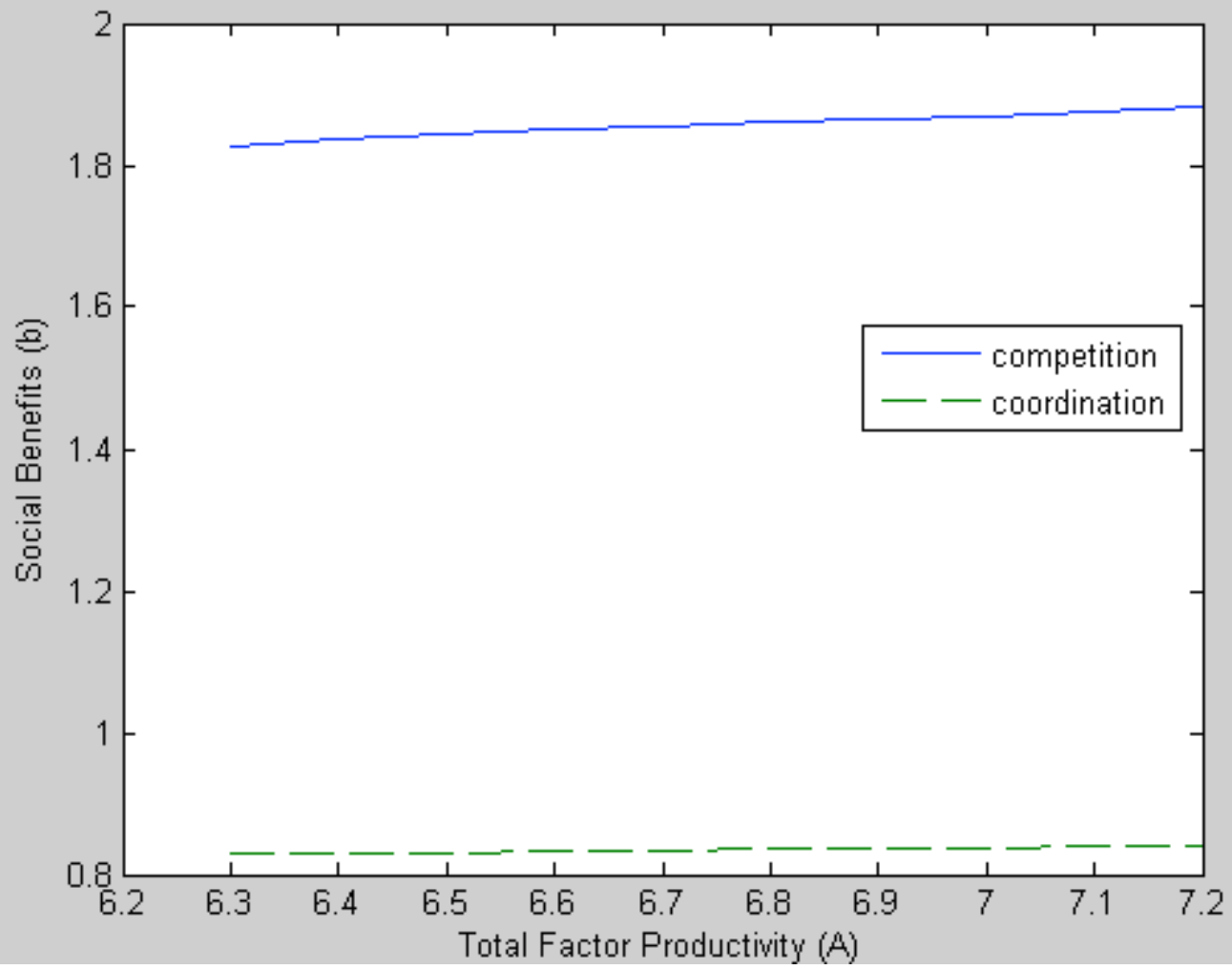

Figure 1: Social Benefits, by Total Factor Productivity: Competition versus Coordination. 


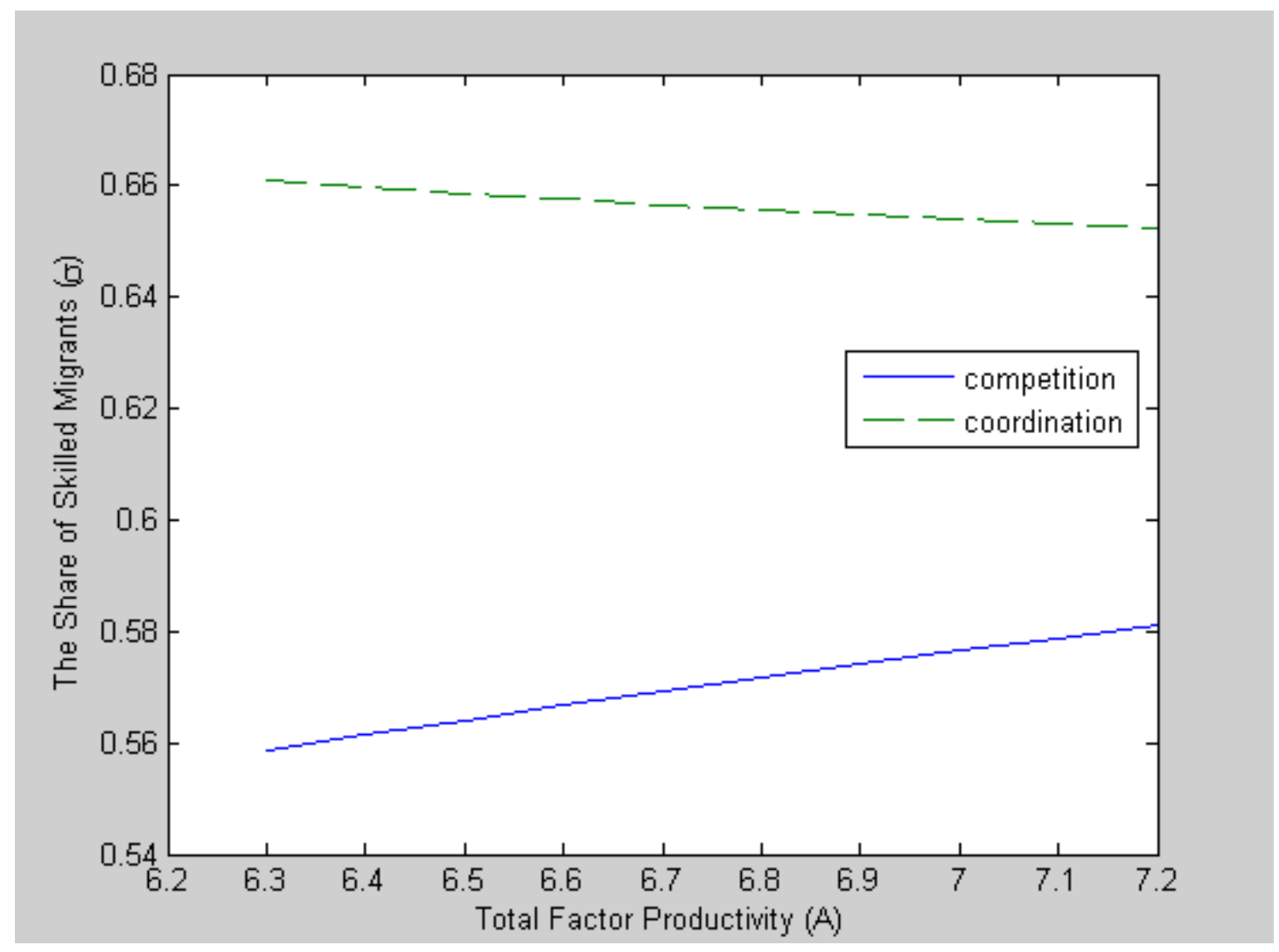

Figure 2: High-Skill Composition of Migration, by Total Factor Productivity: Competition versus Coordination 

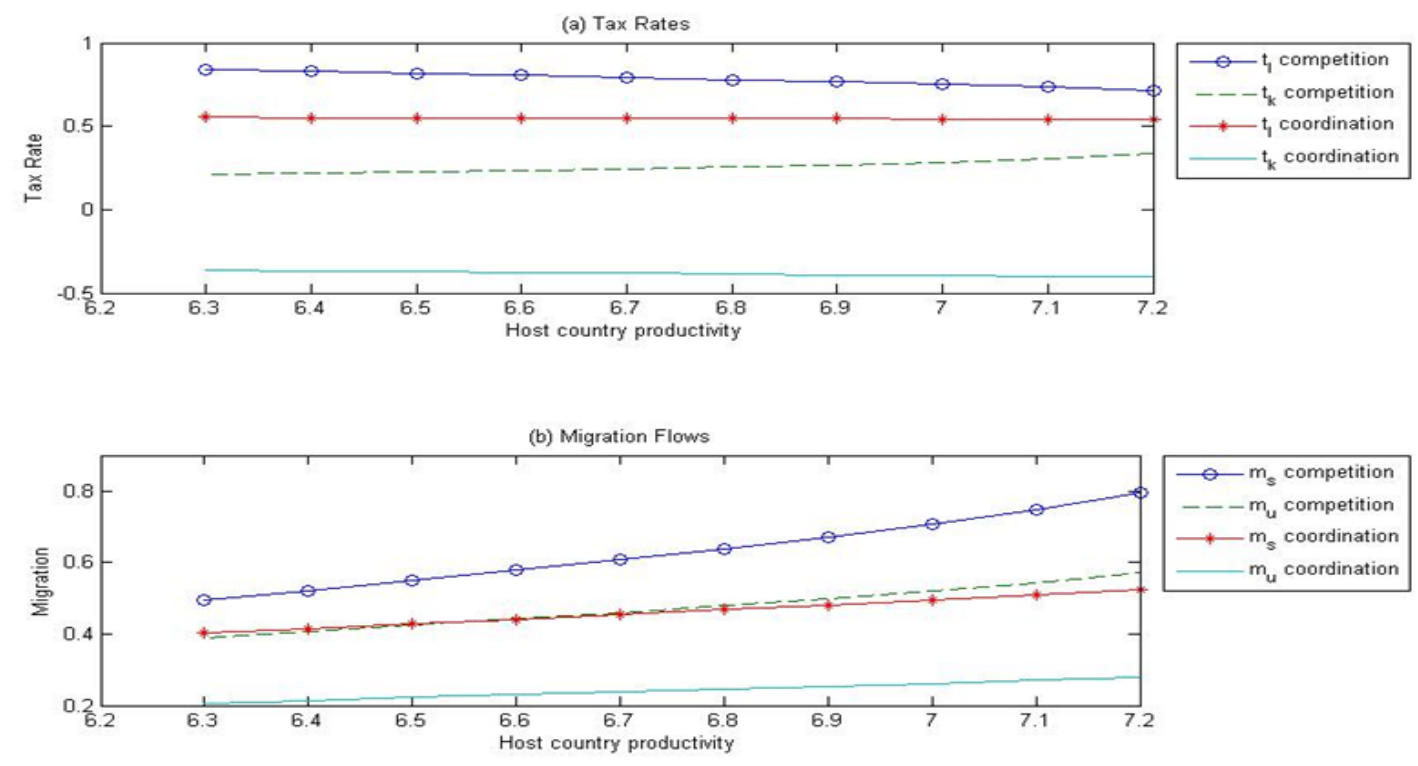

Figure 3: Tax rates and migration volumes, by Total Factor Productivity: Competition versus Coordination

Our main interest is to compare $b$ and $\sigma$ under the two regimes. Interestingly, coordinating the fiscal and migration policies allows the union-member states to offer less generous social benefits than when they compete with each other; see Figure 7.1. The rationale for this result is rooted in a fiscal externality associated with migration.

There are gains and losses brought about by migration. A union-member highskilled native born has an infra-marginal gain from either high-skill or low-skill migration stemming, from the diminishing productivity of either type of labor for a fixed stock of capital (triggering the "business" lobby). The gain stems from the fact that each migrant (whether skilled or low-skilled) is paid according to the productivity of the marginal migrant, which is smaller than the average productivity of the migrants (of the same type). On the other hand, the nativeborn population shares with migrants the tax collected from capital income (recall that migrants have no capital), because the transfer $b$ that the migrants re- 
ceive is not financed fully by their labor income tax. That is, the capital tax revenues paid by the native-born population 'leak' also to the migrants ${ }^{12}$.

The fiscal burden imposed by migration on the high-skilled native-born (both high-skill and low-skill) is reinforced when this migration is composed of lowskill migrants. This is because the low-skilled not only possess no capital; they also have low wages and accordingly pay low labor income taxes ${ }^{13}$.

Each union-member country in a competitive regime evidently balances at the margin the gains and losses from migration. In doing so, each country (being a "utility-taker") takes the well-being of the migrants, $\bar{V}_{s}^{m}$ and $\bar{V}_{u}^{m}$, as given (see equation (5.15)) and the union wide rate of return on capital, $\bar{r}$. It thus ignores the fact that when it adopts a fiscal-migration policy that admits an extra migrant, it raises the well-being that must be accorded to migrants not only by it but also by all other union member countries, in order to elicit the migrant to come in. as a result, it offers migrants too high level of the social benefit (b), and admits a too high share of low-skilled migrants- a "fiscal leakage" externality. Indeed, Figure 2 demonstrates that the union member states admit a higher share of low-skill migrants when they compete with each other than when they cooperate. As expected, the cooperating states, facing an upward-slopping supply of migrants (of both types) exploit their market power by admitting smaller numbers of high-skill and low-skill migrants, as compared to the case when they compete with each other. ${ }^{14}$

\footnotetext{
${ }^{12}$ Fiscal leakage effects in demographic contexts where first analyzed by Razin, Sadka and Swagel (2002a and 2002b).

${ }^{13}$ High-skill migrants, though bringing no capital still pay relatively high taxes on labor income.

${ }^{14}$ Further intuition is gained when one compares the first-order conditions under the coordination regime to those under the competition equilibrium; these conditions are similar except for a subset associated with migration decisions and capital flow decisions. Thus, starting from the coordination equilibrium, these comparisons reveal that an individual member state would like to deviate towards bring in more low-skilled migrants. To elicit the marginal low-skilled migrant and individual member inflict a larger fiscal burden on the rest of the member countries, because they will have to compete for low-skilled migrants. The competitive equilibrium therefore will have relatively more low-skilled migrants and higher social benefits relative to the coordination equilibrium.
} 
Obviously coordination allows the union to exercise monopsony power over migrants. Therefore the migration volumes under the policy-competition regime exceed those under the policy-coordination regime. Specifically, competition over low-skilled migrants, who come with no capital, induces the individual member state to raise the social benefit, $b$, so as to attract more migrants when starting from the coordination equilibrium. As a result, the social benefits in all other member States must also be raised to keep these migrants at their own economy. This amounts to greater income redistribution from the high skilled native-born who are in power to the unskilled immigrants- a negative externality.

\section{8. $\underline{\text { Conclusion }}$}

As we know, there are some significant gains from migration. First, high-skill migration does not impose a fiscal burden on the welfare state. To the contrary, the taxes paid by high-skill migrants generally exceed the benefits they receive. Second, high-skill migration enhances the technological edge of the destination country. Furthermore, even low-skill migrants may still alleviate the finances of a welfare state, which allocates a great deal of its resources to old-age security. ${ }^{15}$ This led us to explore how migrating and fiscal (welfare) policies are jointly determined in a political-economic setup.

However, in the era of the welfare state one can no longer envisage a world of free migration. Indeed, for example, the U.S. has gradually ceased to freely admit migrants after World War I, when it also started to gradually develop the institutions of the welfare state (e.g., the federal income tax, the old-age securi-

\footnotetext{
${ }^{15}$ See Storesletten (2000) for a calibrated over-lapping generations model which analyzes this issue. See also a political-economy dynamic analysis of coalition building in Razin, Sadka, and Suwankiri (2015).
} 
ty, etc.), culminating with the great social institutions in the sixties of the last century (e.g. Medicare) and more recently, in the affordable health care (known as Obama Care). A welfare state is a magnet for migrants, especially the lowskill, the poor, and the old. Therefore, there will arise a political backlash of the native-born against the "free-riders"- the migrants. This does not mean that migration will be altogether banned

Evidently, both the U.S. and the EU are an economic union: There is a single market for goods, capital, finance, and labor. That is, there is free mobility of goods, physical and financial capital, and labor among the member countries of the union. Nevertheless, there is much higher degree of economic policy coordination among the member states of the U.S than of the EU. For instance, the U.S. has a common (federal) income tax system which constitutes the major source of revenues in the union. Similarly, the social security system is more or less uniform across the U.S. There is also a single migration policy set up and enforced by the federal government. In contrast, there is very little coordination on these issues among the member countries of the EU. In essence, they compete with each other on these issues.

We argue that the degree of coordination among the member states potentially contribute a great deal to our understanding of observed policy differences between the EU and the US as economic unions: the generosity of the welfare state and the skill composition of migration.

It is worth noting that the U.S. welfare system has undergone some reforms that gave the states some more leeway in designing the structure and magnitude of public assistance. In particular, the 1996 welfare reform is worth mentioning ${ }^{16}$. Substituted open-ended federal funds with block grants, leaving the states some

\footnotetext{
${ }^{16}$ Specifically: the Personal Responsibility and Work Opportunity Reconciliation Act (RRWORA)
} 
autonomy over individual eligibility criteria; see Blank (1997) for a review of this reform. The reform somewhat weakened the degree of coordination among the states of the U.S. with respect to public assistance programs, making a small step towards the way the EU operates on these issues.

Further evidence of coordination failures in the EU is in the recent wave of migrants and asylum seekers from the Middle East and the Balkans. This forced the European Commission, the EU executive arm, and EU interior ministers to propose a first-step plan to deal with the challenge. The EU`s 28 member states have long been famed for squabbling among themselves when confronting refugee crisis because they lack a federal institutions, as in the US, which can deal in a coordinated fashion.

\section{$\underline{\text { References }}$}

Blank, Rebecca M. (1997), “Policy Watch: The 1996 Welfare Reform,” The Journal of Economic Perspectives, Vol. 11, No. 1 (winter, 1997), pp. 169-177.

Boeri, Tito. (2010). “Immigration to the Land of Redistribution”. Economica 77:651-687.

Boeri, Tito (2008), “Brain Gain: A European Approach”, CESifo Forum, 3 pp. 30-34.

Boeri, Tito, Gordon Howard Hanson, and Barry McCormick, eds. (2002). Immigration Policy and Welfare System: A report for the fondazione Rodolfo Debenedetti. Oxford: Oxford University Press. 
Gornick, Janet, editor, (2013) Income Inequality: Economic Disparities and the Middle Class in Affluent Countries (Studies in Social Inequality), Stanford University press

Goldin, Ian, Geoffrey Camero, and Meera Balarajan (2011). Exceptional People How Migration Shaped Our World and Will Define Our Future, Princeton University Press.

Oates, Wallace E. 1972. Fiscal Federalism, New York: Harcourt Brace.

Razin, Assaf, Efraim Sadka, and Phillip Swagel. (2002a). "The Aging Population and the Size of the Welfare State.” Journal of Political Economy 66(6):467482.

-------.(2002b). “Tax Burden and Migration: A Political Economy Theory and Evidence.” Journal of Public Economics 85 (2): 167-190.

Razin, Assaf, Sadka, Efraim, and Benjarong Suwankiri. 2014.”Migration and the Welfare State: A Dynamic Coalition-Formation Theory.” NBER WPResearch in Economics, Elsevier Publishing, forthcoming.

(2011) Migration and the Welfare State: Political-Economic Policy Formation, the MIT Press, November 2011.

Sargent, Thomas J. (2012), “Nobel Lecture: United States Then, Europe Now.” the Journal of Political Economy, 120(1), pp. 1-40.

Storesletten, K. (2000), "Sustaining Fiscal Policy through Immigration," Journal of Political Economy, 108(2), 300-323.

Tiebout, Charles M. (1956),“A Pure Theory of Local Expenditures,” Journal of Political Economy Vol. 64, No. 5 (Oct., 1956), pp. 416-424.

United Nations. 2013. World Population Prospect, June. 